\title{
Release of Carcinoembryonic Antigen from Human Colon Cancer Cells by Phosphatidylinositol-specific Phospholipase C
}

Todd L. Sack, James R. Gum, Martin G. Low, ${ }^{\star}$ and Young S. Kim

Gastrointestinal Research Laboratory, Veterans Administration Medical Center, and University of California School of Medicine, San Francisco, California 94121; and *Department of Physiology and Cellular Biophysics, College of Physicians \& Surgeons, Columbia University, New York 10032

\begin{abstract}
Carcinoembryonic antigen (CEA) is released from colon cancer cells into the circulation where it is monitored clinically as an indicator of the recurrence or progression of cancer. We have studied the mechanism of CEA membrane attachment and release using the human colonic adenocarcinoma cell line LS-174T, specimens of human colon cancers, and serum from colon cancer patients. CEA release by cells in vitro and in vivo is associated with the conversion of CEA from a membranebound, hydrophobic molecule to a soluble, hydrophilic form with no apparent decrease in molecular mass. When LS-174T cell membranes were incubated with various buffers, proteases, and phospholipases, the only agents that released CEA and converted it to the hydrophilic form were preparations of phosphatidylinositol-specific phospholipase C (PI-PLC). Both $\left[{ }^{3} \mathrm{H}\right]$ ethanolamine and $\left[{ }^{3} \mathrm{H}\right]$ palmitate could be incorporated metabolically into CEA but only palmitate was released by treatment with PI-PLC, consistent with the presence of a glycosyl-phosphatidylinositol linkage. PI-PLC treatment also released significant quantities of CEA from living monolayers and from seven human colon cancer specimens. These experiments suggest that cellular CEA is anchored to membranes by a covalent linkage to a membrane phosphatidylinositol molecule, and that an endogenous phospholipase may be important for releasing CEA in vitro and in vivo.
\end{abstract}

\section{Introduction}

Carcinoembryonic antigen (CEA) ${ }^{1}$ is a membrane-bound glycoprotein expressed by cancerous and to some extent by normal epithelial cells of the gastrointestinal tract and certain other organs (1). Its release by colorectal cancer cells has made serum CEA measurements useful in the management of some patients, but the clinical value of CEA is limited due to the frequent failure of serum concentrations to become elevated until late in the course of colorectal cancer (2).

It is uncertain why many patients with colon cancer have normal serum CEA levels despite the presence of CEA in their

\footnotetext{
Address reprint requests to Dr. Sack, 151-M2, GI Research, VA Medical Center, 4150 Clement Street, San Francisco, CA 94121.

Received for publication 8 October 1987 and in revised form 28 March 1988.

1. Abbreviations used in this paper: CEA, carcinoembryonic antigen; LDH, lactate dehydrogenase; PASA, protein A-positive Staphylococcus aureus; PI-PLC, phosphatidylinositol-specific phospholipase C; VSG, variant surface glycoprotein.
}

The Journal of Clinical Investigation, Inc.

Volume 82, August 1988, 586-593 tumors, as determined histochemically $(3,4)$. Serum levels are undoubtedly the result of many factors, including the cellular CEA content, the rate of CEA release, and the rate of its clearance from the circulation by the liver (5). In addition, the abnormal expression of CEA on the basolateral surface of some cancer cells appears to favor the entry of CEA into the serum (6). Information about the mechanism of glycoprotein release by cancer cells could lead to improved methods for the serological detection of membrane-associated antigens such as CEA.

In the present study, we examined the mechanism of CEA release from the human colon adenocarcinoma cell line LS-174T. These cells release approximately $30 \%$ of their cellular CEA content into the culture medium per day; hence they provide a useful in vitro model for examining CEA release. We demonstrate here that CEA release is accompanied by a conversion of membrane-bound CEA into a soluble, hydrophilic form which resembles that found in the serum of some patients with colon cancer. Furthermore, we have found that phosphatidylinositol-specific phospholipase C (PI-PLC) efficiently releases CEA from isolated LS-174T cell membranes and from specimens of human cancers, whereas a variety of other buffers, proteases, and phospholipases are ineffective. These results suggest that CEA is anchored to cancer cell membranes via a linkage to a glycosyl-phosphatidylinositol moiety, and that in some patients CEA may be released in vivo by the action of an endogenous phospholipase.

\section{Methods}

Materials. Trypsin (type IX), $\alpha$-chymotrypsin (type II), elastase (type III), papain, carboxypeptidase B-DFP, phospholipase C from Bacillus cereus (type III), phospholipase $\mathrm{C}$ from Clostridium perfringens (type XIV), phospholipase D from cabbage (type IV), phospholipase $A_{2}$ from Naja naja, $N$-benzyloxycarbonyl-L-phenylalanine chloromethylketone (ZPCK), and other biochemicals were obtained from the Sigma Chemical Co. (St. Louis, MO). PI-PLC from Staphylococcus aureus was purified as described elsewhere (7); its concentration is expressed as micrograms of protein per milliliter. PI-PLC was also purified from Bacillus thuringiensis (Low et al., manuscript in preparation); one unit of activity $(U)$ is defined as the amount that will release $1 \mu \mathrm{mol} / \mathrm{min}$ of $\left[{ }^{3} \mathrm{H}\right]$ inositol from $\left[{ }^{3} \mathrm{H}\right]$ phosphatidylinositol at $\mathrm{pH} 7$ in the presence of $0.1 \%$ deoxycholate. Rabbit anti-CEA was obtained from Dako Corp. (Santa Barbara, CA) and protein A-positive fixed $S$. aureus (PASA) from Boehringer-Mannheim Biochemicals (Indianapolis, IN). "Ultrapure" sucrose was purchased from Schwarz-Mann (Orangeburg, NY). Reagents for sodium dodecyl sulfate-polyacrylamide gel electrophoresis (SDS-PAGE) were obtained from Bio-Rad Laboratories (Richmond, CA). $\left[{ }^{35} \mathrm{~S}\right]$ cysteine $(1,251 \mathrm{Ci} / \mathrm{mmol}),\left[9,10-{ }^{3} \mathrm{H}\right]$ palmitic acid $(40$ $\mathrm{Ci} / \mathrm{mmol}),\left[1-{ }^{3} \mathrm{H}\right]$ ethanolamine $(23 \mathrm{Ci} / \mathrm{mmol})$, and $\left[{ }^{14} \mathrm{C}\right]$ glucose were obtained from Amersham Corp. (Arlington Heights, IL), and $\left[{ }^{3} \mathrm{H}\right]-$ mucin was prepared as described previously (8). Samples of human serum and human colon cancers, obtained with the approval of the 
UCSF Human Experimentation Committee, were stored at $-20^{\circ} \mathrm{C}$ in small aliquots until the time of the assays.

Cell culture and harvest. LS-174T human colon cancer cells (9) were grown on plastic tissue culture dishes (Falcon Labware, Oxnard, CA) in Dulbecco's modified Eagle's medium-H21 (DME) supplemented with $5 \%$ fetal bovine serum (FBS), penicillin, and streptomycin as previbusly described (10). Dialyzed FBS was prepared by extensively dialyzing FBS against PBS as $4^{\circ} \mathrm{C}$. For serum-free experiments, serum was replaced with epidermal growth factor $(1 \mathrm{ng} / \mathrm{ml})$, glucagon $(200 \mathrm{ng} / \mathrm{ml})$, human transferrin $(2 \mu \mathrm{g} / \mathrm{ml})$, and bovine insulin $(5$ $\mu \mathrm{g} / \mathrm{ml}$ ). The possibility of contamination with mycoplasma was excluded by $\left[{ }^{3} \mathrm{H}\right] \mathrm{DNA}$ hybridization probe assay (Gen-Probe Inc, San Diego, CA). Culture medium containing released CEA was produced by incubating confluent monolayers with medium for up to $24 \mathrm{~h}$ using 3 and $15 \mathrm{ml}$ of medium for $35-$ and $100-\mathrm{mm}$ dishes, respectively. The medium was then made $0.1 \mathrm{mM}$ phenylmethylsulfonyl fluoride (PMSF), centrifuged at $600 \mathrm{~g}$ for $10 \mathrm{~min}$ to remove floating cells, and stored at $-60^{\circ} \mathrm{C}$ until used. When necessary, medium was concentrated 15 -fold at $4^{\circ} \mathrm{C}$ using an Amicon chamber with a PM10 membrane (Amicon Corp., Lexington, MA), a process requiring $\sim 90 \mathrm{~min}$. Cell homogenate was prepared by washing the monolayers three times with iced isotonic phosphate-buffered saline (PBS, pH 7.4), scraping with a rubber policeman, incubating the cells in $10 \mathrm{mM}$ Tris- $\mathrm{HCl}$ (pH 7.4) on ice for $10 \mathrm{~min}$, and performing 30 strokes with a Dounce homogenizer. Cell membranes were prepared under sterile conditions by centrifuging cell homogenates for $1 \mathrm{~h}$ at $100,000 \mathrm{~g}$ at $4^{\circ} \mathrm{C}$ in a $50 \mathrm{Ti}$ rotor (Beckman Instruments, Inc., Fullerton, $\mathrm{CA}$ ). The pellet was reconstituted in $10 \mathrm{mM}$ Tris- $\mathrm{HCl}, \mathrm{pH} 7.4,100 \mathrm{mM} \mathrm{NaCl}$ (buffer A) to a protein concentration of $2.3 \mathrm{mg} / \mathrm{ml}$, and frozen at $-60^{\circ} \mathrm{C}$.

Incorporation of radioactive precursors. Incorporation of radioactive cysteine, palmitate, and ethanolamine was performed by first incubating confluent LS-174T cells in 60-mm dishes overnight in DME containing 5\% dialyzed FBS but omitting the nonradioactive form of the appropriate precursor. The cells were then incubated $24 \mathrm{~h}$ at $37^{\circ} \mathrm{C}$. in this medium plus either $\left[{ }^{35} \mathrm{~S}\right]$ cysteine $\left(1 \mathrm{mCi}\right.$ per dish), $\left[{ }^{3} \mathrm{H}\right]-$ ethanolamine $\left(200 \mu \mathrm{Ci}\right.$ per dish), or $\left[{ }^{3} \mathrm{H}\right]$ palmitate $(1 \mathrm{mCi}$ per dish). The monolayers were then washed extensively with iced DME, scraped, and sonicated, and cell membranes were prepared and stored as described above.

Biochemical assays. Lactate dehydrogenase (LDH) was measured using the method of Bergmeyer et al. (11). Protein content was assayed by dye binding (12) using reagents from Bio-Rad Laboratories and bovine serum albumin (BSA) as a standard. For CEA determination, specimens and human CEA standards were solubilized with $0.1 \%$ $\mathrm{NP}-40$ and assayed in duplicate by enzyme-linked polyclonal immunoassay (ELISA, Abbott Laboratories, N. Chicago, IL).

Isopycnic sucrose density gradients. Sucrose density gradient analysis of LS-174T cell homogenate and concentrated serum-free 24-h culture medium was performed using a modification of the method of Knipe et al. (13). Samples were made 55\% sucrose (wt/vol) and $3 \mathrm{ml}$ was overlaid with a 9-ml discontinuous gradient of sucrose prepared in buffer A containing $1 \mathrm{mM}$ EDTA and $0.1 \mathrm{mM}$ PMSF (buffer B). Gradients were centrifuged at $100,000 \mathrm{~g}$ for $16 \mathrm{~h}$ at $4^{\circ} \mathrm{C}$ and then collected from the bottom in $1.25-\mathrm{ml}$ fractions. Fraction densities were determined with a model 10450 Abbe refractometer (American Optical Corp., Buffalo, NY).

Immunoprecipitation and immunoblotting. To immunoprecipitate CEA, $700 \mu \mathrm{l}$ of each sample was combined with $700 \mu \mathrm{l}$ of buffer C (10 $\mathrm{mM}$ Tris- $\mathrm{HCl}, \mathrm{pH} 7.6,0.5 \mathrm{M} \mathrm{NaCl}, 1 \mathrm{mg} / \mathrm{ml} \mathrm{BSA}, 1 \% \mathrm{NP}-40,1 \mathrm{mM}$ EDTA, and $0.1 \mathrm{mM}$ PMSF). Immunoprecipitation of CEA in human serum samples was preceded by incubation with $1 \mathrm{ml}$ of $10 \%$ PASA for $1 \mathrm{~h}$ at $4^{\circ} \mathrm{C}$ and centrifugation at $600 \mathrm{~g}$ for $10 \mathrm{~min}$ in order to remove human immunoglobulins. In the experiments using radioactive precursors, aliquots of membranes were used containing equal trichloroacetic acid-precipitable counts per minute. Immunoprecipitation was performed as described previously (14) using $5 \mu$ l of rabbit anti-CEA and $100 \mu \mathrm{l}$ of washed $10 \%$ PASA per sample. After washing (14), immunoprecipitates were boiled $5 \mathrm{~min}$ in electrophoresis buffer con- taining $5 \%$ (vol/vol) $\beta$-mercaptoethanol and centrifuged to remove the PASA pellet. Electrophoresis was conducted on $7 \%$ polyacrylamide gels in the presence of SDS (SDS-PAGE) (14). For immunoblot analysis, proteins were transferred electrophoretically overnight to nitrocellulose, soaked for $1 \mathrm{~h}$ at $25^{\circ} \mathrm{C}$ in blocking buffer $(10 \mathrm{mM}$ Tris- $\mathrm{HCl}$, $0.15 \mathrm{M} \mathrm{NaCl}, 2 \mathrm{mg} / \mathrm{ml} \mathrm{BSA}$, and $1 \mathrm{mg} / \mathrm{ml} \mathrm{NaN}_{3}$ ), and soaked for $1 \mathrm{~h} \mathrm{in}$ $0.5 \%$ (wt/vol) Carnation nonfat dry milk in PBS. After rinsing in PBS, immunoblotting (Western blotting) was performed at $37^{\circ} \mathrm{C}$ by incubating the paper in a 1:500 dilution of anti-CEA in blocking buffer followed by incubation with ${ }^{125}$ I-labeled protein $A(15)$. After extensive washing, the nitrocellulose membranes were dried and autoradiography at $4^{\circ} \mathrm{C}$ was performed using Kodak XAR2 film and Dupont Cronex intensifying screens. The intensity of the $200-\mathrm{kD}$ autoradiogram bands was determined using a densitometer (E-C Apparatus Corp., St. Petersburg, FL).

Column chromatography. A $1.2 \times 83-\mathrm{cm}$ Sepharose CL-4B column equilibrated with PBS was calibrated using $\left[{ }^{3} \mathrm{H}\right]$ mucin (8), thyroglobulin, ferritin, transferrin, and $\left[{ }^{14} \mathrm{C}\right]$ glucose. Fresh LS-174T $24-\mathrm{h}$ culture medium was applied and eluted at room temperature in $2.5-\mathrm{ml}$ fractions at a flow rate of $0.18 \mathrm{ml} / \mathrm{min}$. CEA content was determined by ELISA.

Triton $X-114$ detergent partitioning. Detergent partitioning with Triton X-114 was performed using a modification of the method of Bordier (16). Samples $(235 \mu \mathrm{l})$ were combined with $175 \mu \mathrm{l}$ of buffer A and $90 \mu \mathrm{l}$ of $5 \%$ Triton X-114. This was vortexed, sonicated for $10 \mathrm{~s}$ on ice, overlaid on a $750-\mu l$ cushion of $9 \%$ sucrose in buffer B (wt/vol) in a $12 \times 75-\mathrm{mm}$ tube, and then partitioned into detergent and aqueous layers at $30^{\circ} \mathrm{C}$ as described (16). The lower $250-\mu l$ of the final detergent layer was used as the detergent phase in subsequent analyses, and the upper $500 \mu \mathrm{l}$ of the final aqueous layer was used as the aqueous phase. Each phase was analyzed for CEA content using immunoprecipitation followed by SDS-PAGE and immunoblotting. Based upon experiments using BSA as a standard protein, separation of hydrophobic from hydrophilic macromolecules was complete under these conditions (not shown).

Incubation of membranes with proteases and phospholipases. 235 $\mu \mathrm{l}$ of LS-174T cell membranes was thawed, sonicated for $10 \mathrm{~s}$, combined with $175 \mu$ l of a protease or phospholipase solution (in buffer $A$ except where stated otherwise), and incubated for $6 \mathrm{~h}$ at $37^{\circ} \mathrm{C}$ in a rapidly shaking water bath. After incubation, reactions were stopped by rapidly cooling to $4^{\circ} \mathrm{C}$ and adding $22 \mu \mathrm{l}$ of the appropriate enzyme inhibitor. The final concentration of inhibitor for each protease (in parentheses) was $4 \mathrm{mM}$ benzamidine (trypsin and elastase), $0.4 \mathrm{mM}$ ZPCK (chymotrypsin), $5 \mathrm{mM}$ EDTA (carboxypeptidase-B), and $4 \mathrm{mM}$ iodoacetate (papain and bromelain).

Incubation of colon cancer cell monolayers and human cancer specimens with PI-PLC. Confluent LS-174T monolayers were washed three times with DME, incubated for $6 \mathrm{~h}$ at $37^{\circ} \mathrm{C}$ with DME or with DME containing PI-PLC from $B$. thuringiensis $(3 \mathrm{U} / \mathrm{ml})$, and the cells and medium were harvested for CEA determination by ELISA. Frozen human colon cancer specimens were minced finely at $4^{\circ} \mathrm{C}$, washed three times with iced DME, and incubated with DME or with DME containing PI-PLC as described above. The samples then were centrifuged at $100,000 \mathrm{~g}$ at $4^{\circ} \mathrm{C}$ for $1 \mathrm{~h}$, and the pellets and supernates were assayed for CEA content by ELISA to determine cell content and CEA release, respectively.

\section{Results}

$C E A$ release and cell viability. Confluent LS-174T cell monolayers released $\sim 30 \%$ of their cellular CEA content into the culture medium in $24 \mathrm{~h}$ (Fig. 1). This release rate was observed using medium containing 5\% FBS or with serum-free medium supplemented with growth factors (not shown). In order to determine that CEA release was not due to cell death, CEA release was compared with the release of the cytosolic enzyme 


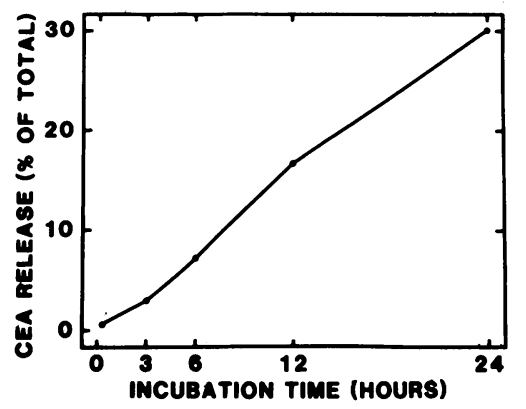

Figure 1. Rate of release of CEA from LS-174T cells. Fresh medium containing 5\% FBS was added to confluent monolayers and incubated for the times shown. After incubation, cells and medium were harvested and assayed for CEA content by ELISA. Total CEA is the sum of the cellular and medium CEA content at each incubation time. Each value is the mean result from two $35-\mathrm{mm}$ petri dishes. Specific content of cellular CEA averaged $480 \mathrm{ng} / \mathrm{mg}$ cell protein.

LDH. LDH release was neglibible under these conditions (Table I). In addition, over $99 \%$ of cells excluded $0.4 \%$ Trypan blue dye in situ.

Comparison of cellular and medium CEA. In intact cells, CEA is membrane åssociated (i7). In light of this, we sought to characterize the molecular form of released CEA. First, aliquots of freshly harvested cell homogenate and 24-h culture medium were separately centrifuged at $100,000 \mathrm{~g}$ for $1 \mathrm{~h}$ at $4^{\circ} \mathrm{C}$ in a SW-41 rotor. After centrifugation, the pellets and supernatants were assayed for CEA content by ELISA. Because there were no visible pellets in the medium samples, each medium supernatant was collected from the top in four fractions of $2.5 \mathrm{ml}$ each, the bottom fraction $(1.2 \mathrm{ml})$ was sonicated in the centrifugation tube to resuspend any pelleted CEA, and ELISA was then performed on each fraction. In three experiments, $94.5 \%$ of homogenate CEA appeared in the pellet (range: $91.8-97.8 \%$ ). For the medium, however, there was no detectable gradient in CEA content from the top to the bottom of the sample, indicating that little or no sedimentation of medium CEA occurred and that released CEA is present predominantly in a soluble form.

Next, isopycnic sucrose density gradient analysis of cell homogenate and serum-free 24-h culture medium was performed and the CEA content of each fraction determined by CEA immunoprecipitation and immunoblotting. Cellular CEA floated upwards to the region of the gradient with a density of $\sim 1.14-1.16 \mathrm{~g} / \mathrm{ml}$ (Fig. $2 A$ ), the buoyant density of plasma membranes (18). In contrast, most of the medium

Table I. Release of $L D H$ and CEA from Confluent LS-174T Cells*

\begin{tabular}{ccc}
\hline Incubation time & CEA release & LDH release \\
\hline$h$ & $\%$ & $\%$ \\
0.1 & 0.50 & 0.8 \\
3.0 & 2.98 & 1.1 \\
6.0 & 7.41 & 1.2 \\
12.0 & 16.8 & 0.55 \\
24.0 & 30.1 & 0.52
\end{tabular}

\footnotetext{
* Release is expressed as the percentage of the total CEA or LDH (medium plus cellular) which is released into the medium. CEA is determined by ELISA.
}

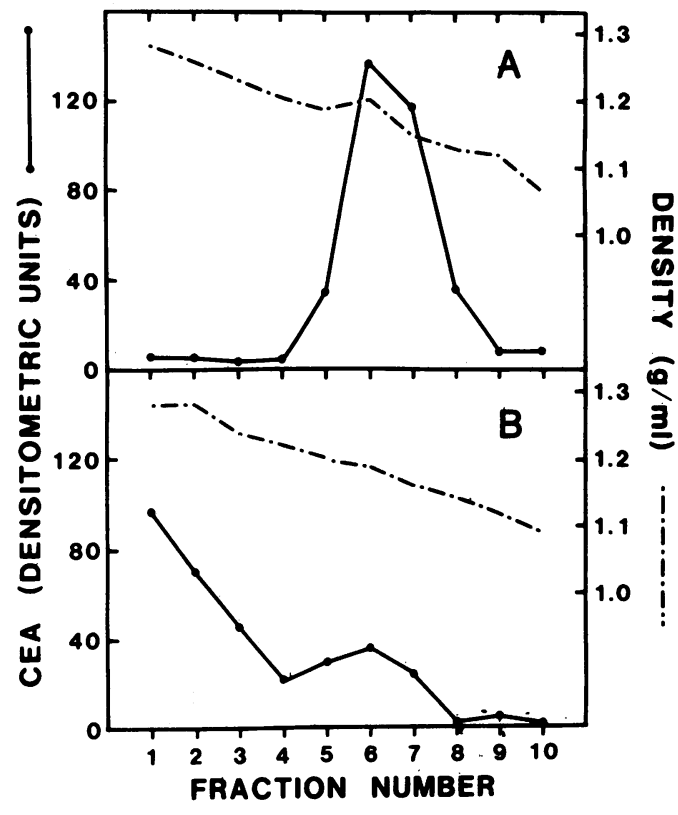

Figure 2. Isopycnic sucrose density gradient analysis of CEA in LS-174T cell homogenate and culture medium. Samples of $(A)$ cell homogenate and $(B)$ serum-free 24 -h culture medium were made $55 \%$ sucrose, and isopycnic sucrose density gradients were prepared. Gradient fractions were analyzed for CEA content using CEA immunoprecipitation followed by immunoblotting and autoradiography. The intensity of the $180-\mathrm{kD}$ bands was determined by densitometer and the density of each fraction was determined using a refractometer.

CEA remained at the bottom of the tube in the high-density zone, with only a small portion rising to the low-density region (Figure $2 \mathrm{~B}$ ). This suggests that cellular CEA is membrane associated, while CEA released into the medium is a soluble glycoprotein.

To further characterize released CEA, freshly harvested 24-h culture medium was applied to a Sepharose CL-4B column and eluted with PBS containing 0.1 mM PMSF at room temperature (Fig. 3). Medium CEA eluted as an aggregate of $\sim 500 \mathrm{kD}$; only a small proportion appeared in the void volume where membranous material would be expected to elute (19).

Triton X-114 partitioning of cell homogenate and serumfree 24-h culture medium was performed next, followed by immunoprecipitation with anti-CEA, SDS-PAGE, and immunoblotting (Fig. 4). Homogenate CEA partitioned almost entirely into the detergent phase in a hydrophobic form, whereas released CEA behaved as a hydrophilic molecule by partitioning into the aqueous phase. There was no difference in the apparent molecular mass of homogenate CEA and medium CEA as determined by SDS-PAGE.

The results of these experiments confirm that cellular CEA is largely in a membrane-associated, hydrophobic form, and indicate that CEA release is associated with the conversion of CEA to a soluble, hydrophilic molecule with approximately the same subunit molecular size.

Triton X-114 partitioning of LS-174T membranes incubated with proteases and phospholipases. LS-174T cell membranes were incubated under various conditions in order to determine the nature of the CEA membrane-binding domain and to identify the conditions that convert membrane-asso- 


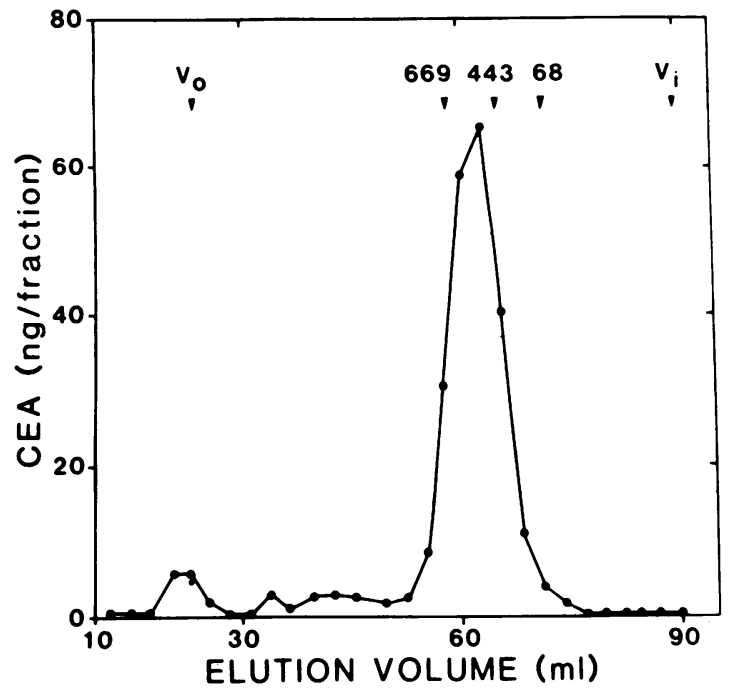

Figure 3. Sepharose CL-4B column chromatography of LS-174T culture medium. 24-h culture medium was applied to a Sepharose CL-4B column and the eluted fractions were assayed for CEA content by ELISA. Elution positions of molecular mass standards are indicated by arrowheads: $\left[{ }^{3} \mathrm{H}\right]$ mucin $\left(V_{\mathrm{o}}\right)$, thyroglobulin $(669 \mathrm{kD})$, ferritin $(443 \mathrm{kD})$, transferrin $(68 \mathrm{kD})$, and $\left[{ }^{14} \mathrm{C}\right]$ glucose $\left(V_{\mathrm{i}}\right)$.

ciated CEA to the form observed after its release into the culture medium and into patient sera.

High concentrations of proteases had no effect upon the hydrophobicity of cellular CEA (Fig. $5 A$ ). The same results were obtained when membranes were sonicated with $1 \%$ Triton $\mathrm{X}-114$ for $20 \mathrm{~s}$ at $4^{\circ} \mathrm{C}$ before incubation with the enzymes (not shown), indicating that the failure of proteases to affect the molecular form of CEA is unlikely to be due to a lack of access of the enzymes to CEA cleavage sites. That the enzymes were proteolytically active under these conditions was verified

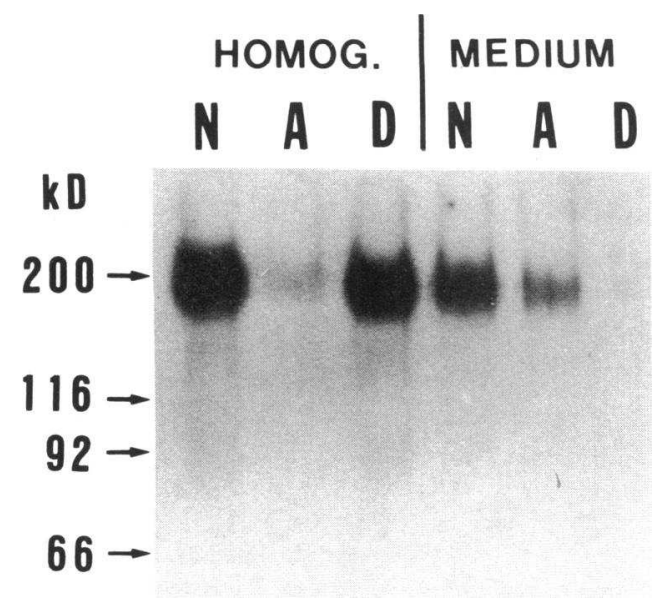

Figure 4. Triton X-114 partitioning of CEA in LS-174T cell homogenate and culture medium. Cell homogenate and serum-free 24-h culture mediụm were partitioned with Triton X-114, immunoprecipitated with anti-CEA, and immunoblotted. Lanes labeled $N$ represent samples mixed with Triton X-114 and not partitioned; $A$ represents the aqueous phase after partitioning; and $D$ represents the detergent phase. Molecular mass standards are indicated by arrows: myosin (200 kD); $\beta$-galactosidase (116 kD); phosphorylase-b (92 $\mathrm{kD})$; and BSA (66 kD).

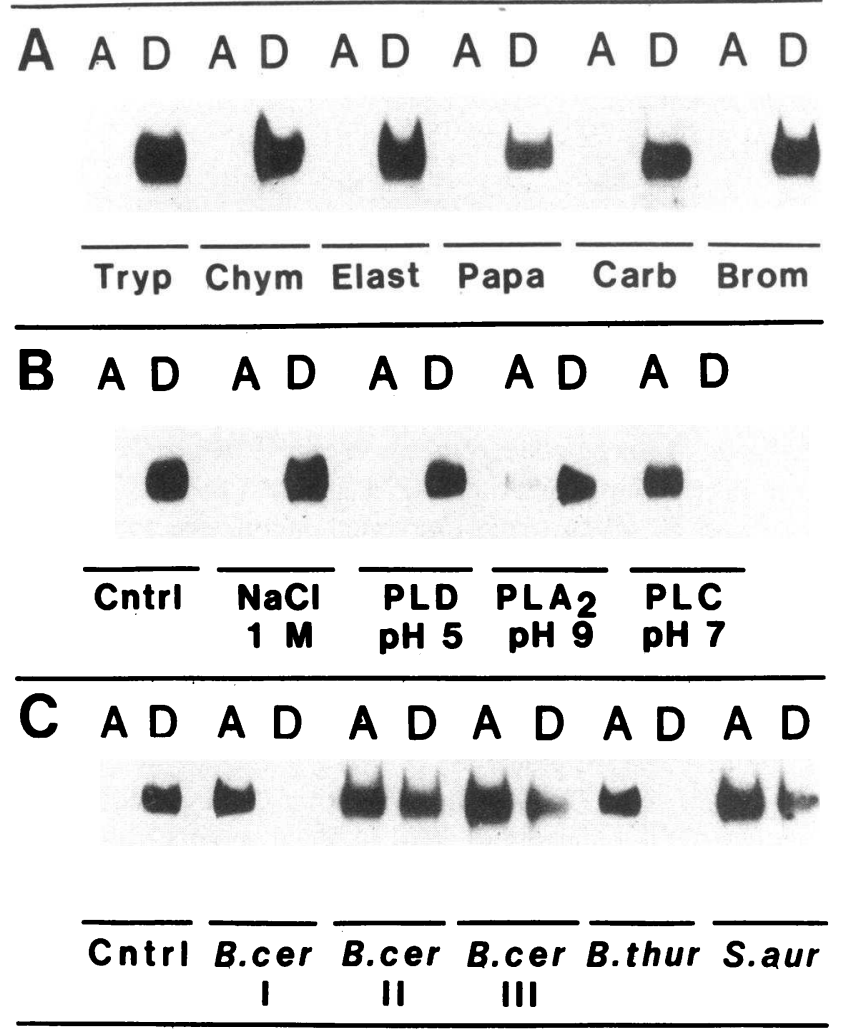

Figure 5. Incubation of LS-174T cell membranes with proteases and phospholipases. LS-174T cell membranes $(235 \mu \mathrm{l})$ were incubated for $6 \mathrm{~h}$ at $37^{\circ} \mathrm{C}$ with various proteases, buffers, and phospholipases, after which the appropriate protease inhibitors were added (see Methods), and the samples partitioned with Triton X-114, immunoprecipitated with anti-CEA, and immunoblotted. $A$ and $D$ indicate the aqueous and detergent phases, respectively. (A) Tryp, $1 \mathrm{mg} / \mathrm{ml}$ trypsin; Chym, $1 \mathrm{mg} / \mathrm{ml}$ chymotrypsin; Elast, $1 \mathrm{mg} / \mathrm{ml}$ elastase; Papa $1 \mathrm{mg} / \mathrm{ml} \mathrm{pa-}$ pain; $C a r b, 0.8 \mathrm{mg} / \mathrm{ml}$ carboxypeptidase-B; Brom, $10 \mathrm{mg} / \mathrm{ml}$ bromelain. (B) Cntrl, buffer A only; $1 \mathrm{M} \mathrm{NaCl}$, buffer A with $1 \mathrm{M} \mathrm{NaCl}$; $P L D, 50 \mathrm{U} / \mathrm{ml}$ phospholipase D in $10 \mathrm{mM}$ Tris- $\mathrm{HCl}, \mathrm{pH} 5.6,100$ $\mathrm{mM} \mathrm{NaCl}, 50 \mathrm{mM} \mathrm{CaCl}{ }_{2} ; P L A_{2}, 5 \mathrm{U} / \mathrm{ml}$ phospholipase $\mathrm{A}_{2}$ in 10 $\mathrm{mM}$ Tris- $\mathrm{HCl}$, pH 9.0, $100 \mathrm{mM} \mathrm{NaCl}, 5 \mathrm{mM} \mathrm{CaCl}{ }_{2} ; P L C, 5 \mathrm{U} / \mathrm{ml}$ phospholipase $\mathrm{C}$ from Bacillus cereus in buffer A. (C) Cntrl, buffer $\mathrm{A}$ only; $B$. cer $I, 5 \mathrm{U} / \mathrm{ml}$ PLC from $B$. cereus with $0.5 \mathrm{mM} o$-phenanthroline; $B$. cer II, $0.5 \mathrm{U} / \mathrm{ml}$ PLC from $B$. cereus; $B$. cer III, 0.5 $\mathrm{U} / \mathrm{ml}$ from $B$. cereus with $0.5 \mathrm{mM} o$-phenanthroline; $B$. thur, 13 $\mathrm{U} / \mathrm{ml}$ PI-PLC from B. thuringiensis; S. aur, $170 \mu \mathrm{g} / \mathrm{ml}$ PI-PLC from $S$. aureus.

with the protease assay of Beynon et al. (20) using azocasein as substrate (results not shown).

Fig. $5 B$ shows the results of incubating cell membranes with different buffers and phospholipases. Incubation with 1 $\mathrm{M} \mathrm{NaCl}$ did not alter CEA hydrophobicity, indicating that ionic interactions are not responsible for this aspect of the molecular form of CEA. Phospholipase D (from cabbage) and phospholipase $\mathrm{A}_{2}$ (from Naja naja), incubated under the conditions optimal for each enzyme, also had no effect. However, incubation with $5 \mathrm{U} / \mathrm{ml}$ of partially purified PLC from $B$. cereus efficiently converted all the CEA to the hydrophilic form.

Two types of PLC produced by $B$. cereus have been described, a phosphatidylinositol-specific PLC (PI-PLC) and a broad-specificity PLC which cleaves the phosphodiester bond of phosphatidylcholine and certain other phospholipids but 
not of phosphatidylinositol (21). Commercial preparations of $B$. cereus PLC contain variable amounts of PI-PLC (22). To determine which PLC is responsible for changing the molecular form of CEA, incubations were performed with PLC of $B$. cereus in the presence of a high concentration of 0 -phenanthroline, an inhibitor of the broad-specificity PLC (22). Membrane CEA was fully converted to the hydrophilic form in the presence of $0.5 \mathrm{mM}$ o-phenanthroline, suggesting that the changes in CEA hydrophobicity caused by this preparation of $B$. cereus PLC are due to PI-PLC activity (Fig. $5 C$ ). The inhibitor also had no effect when incubations were performed using a rate-limiting concentration of the $B$. cereus PLC $(0.5$ $\mathrm{U} / \mathrm{ml}$ ). In addition, bacterial PI-PLC purified from $B$. thuringiensis and $S$. aureus each converted membrane-associated CEA to the hydrophilic form (Fig. $5 C$ ). These results indicate that a PI-PLC is responsible for changing CEA from the hydrophobic to the hydrophilic molecular form.

Effects of proteases and phospholipases upon CEA release from $L S-174 T$ membranes. The preceding experiments demonstrate that PI-PLC efficiently converts hydrophobic CEA to a hydrophilic form. To determine whether this treatment also solubilizes CEA, aliquots of LS-174T cell membranes were incubated with various buffers, proteases, or phospholipases for $1 \mathrm{~h}$ at $37^{\circ} \mathrm{C}$ in a shaking water bath, centrifuged at 100,000 $g$ for $1 \mathrm{~h}$ at $4^{\circ} \mathrm{C}$, and CEA assays were performed on the pellets and supernatants. As shown in Table II, all three preparations of PI-PLC rapidly released the membrane-associated CEA. No other buffers or enzymes had a significant effect, including a preparation of broad-specificity PLC produced by $C$. perfringens. Hence, PI-PLC both eonverts CEA to a hydrophilic form and releases it from membranes.

Incorporation of radiolabeled precursors into $C E A$ and release by PI-PLC. The data presented above suggest that CEA may be attached to membranes by a recently described glyco-

Table II. CEA Released from LS-174T Cell Membranes by Incubation with Various Enzymes and Buffers*

\begin{tabular}{|c|c|c|}
\hline Incubation condition & Concentration & $\begin{array}{l}\text { Percent } \\
\text { released }\end{array}$ \\
\hline No enzyme & Buffer A, pH 7.4 & 6.0 \\
\hline PLC, B. cereus & $5 \mathrm{U} / \mathrm{ml}$ & 82.6 \\
\hline PI-PLC, B. thuringiensis & $13 \mathrm{U} / \mathrm{ml}$ & 78.1 \\
\hline PI-PLC, S. aureus & $170 \mu \mathrm{g} / \mathrm{ml}$ & 81.1 \\
\hline PLC, C. perfringens & $5 \mathrm{U} / \mathrm{ml}$ & 6.5 \\
\hline PLD, cabbage & $\begin{array}{l}50 \mathrm{U} / \mathrm{ml} \text { in } 50 \mathrm{mM} \mathrm{CaCl}_{2} \\
\text { pH } 5.6\end{array}$ & 3.4 \\
\hline $\mathrm{PLA}_{2}$, Naja naja & $5 \mathrm{U} / \mathrm{ml}$ in $5 \mathrm{mM} \mathrm{CaCl}_{2}$, pH 9.0 & 4.3 \\
\hline Trypsin & $1 \mathrm{mg} / \mathrm{ml}$ & 2.3 \\
\hline Chymotrypsin & $1 \mathrm{mg} / \mathrm{ml}$ & 14.2 \\
\hline Papain & $1 \mathrm{mg} / \mathrm{ml}$ in $5 \mathrm{mg} / \mathrm{ml}$ cysteine & 8.1 \\
\hline Bromelain & $10 \mathrm{mg} / \mathrm{ml}$ in $5 \mathrm{mg} / \mathrm{ml}$ cysteine & 17.2 \\
\hline Carboxypeptidase B & $65 \mathrm{U} / \mathrm{ml}$ & 4.3 \\
\hline $1 \mathrm{M} \mathrm{NaCl}$ & Tris-HCl 10 mM, pH 7.4 & 3.8 \\
\hline
\end{tabular}

* Cell membranes were incubated for $1 \mathrm{~h}$ at $37^{\circ} \mathrm{C}$ with the above enzymes (dissolved in buffer A except as otherwise listed) or buffers. After incubation, each protease was inhibited with the appropriate inhibitor and the samples centrifuged at $100,000 \mathrm{~g}$ for $1 \mathrm{~h}$ at $4^{\circ} \mathrm{C}$. Release is expressed as the percentage of total CEA (pellet plus supernate) which appears in the supernate. Each value is the mean for two incubations assayed by ELISA in duplicate. syl-phosphatidylinositol linkage (23). The membrane anchor, which is still poorly understood, is believed to consist of a membrane phosphatidylinositol covalently linked at the 6-hydroxyl of the inositol to a short oligosaccharide. At the terminus of this oligosaccharide is an ethanolamine which is amidelinked to the $\alpha$-carboxyl group at the $\mathrm{COOH}$-terminus of the glycoprotein. In order to determine biochemically whether these structures are present in membrane-bound CEA, LS-174T cells were incubated for $24 \mathrm{~h}$ with $\left[{ }^{35} \mathrm{~S}\right]$ cysteine, $\left[{ }^{3} \mathrm{H}\right]$ palmitate, or $\left[{ }^{3} \mathrm{H}\right]$ ethanolamine and cell membranes were prepared. As şhown in Fig. 6, cysteine, palmitate, and ethanolamine were each detectable in immunoprecipitable CEA (lanes 2, 5, and 7). Incubations with PI-PLC were performed to determine the sites at which these precursors are incorporated into CEA. PI-PLC converted the $\left[{ }^{35}\right.$ S]cysteine-labeled CEA from the hydrophobic form to the hydrophilic form (lanes 1-4), confirming that the enzyme was active under the conditions which were employed. In contrast, $\left[{ }^{3} \mathrm{H}\right]$ palmitate was removed from CEA by PI-PLC treatment (lane 6), whereas ethanolamine was still present (lane 8 ). The removal of palmitate and retention of ethanolamine by PI-PLC are fully consistent with the presence of a glycosyl-phosphatidylinositol linkage (23).

$C E A$ release from $L S-174 T$ monolayers and human colon cancer specimens. The ability of PI-PLC to release CEA from intact LS-174T cells and from previously frozen human colon cancer specimens was studied by incubating confluent monolayers or minced colon cancer specimens with serum-free DME in the presence or absence of PI-PLC from B. thuringiensis (Table III). For the monolayers, CEA assays were performed on the cells and medium at 3 and $6 \mathrm{~h}$ of incubation; the cancer specimens were ultracentrifuged after $3 \mathrm{~h}$ and assays performed on the pellets and supernatants. By $3 \mathrm{~h}$, $59.4 \% \pm 2.0 \%$ (mean \pm SE, $n=4)$ of the total CEA of LS-174T cells was released into the medium in the presence of PI-PLC, compared with $1.6 \% \pm 0.1 \%$ for control dishes. No further CEA was released by PI-PLC at $6 \mathrm{~h}$. PI-PLC did not alter cellular morphology of the cultured cells or appear to affect cell viability based upon the exclusion of trypan blue dye. Similarly, this

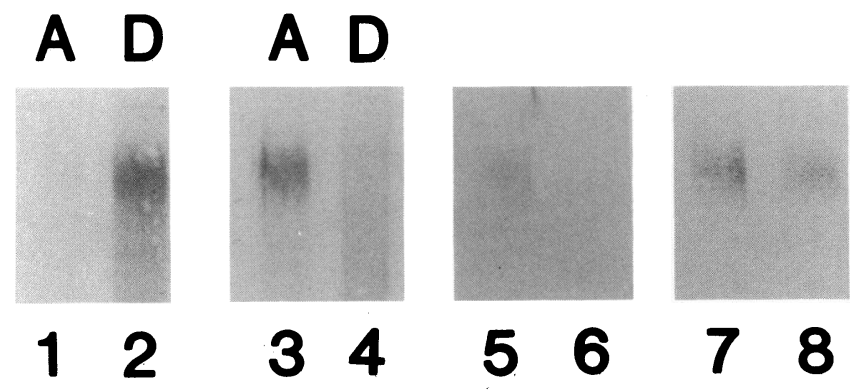

Figure 6. Incorporation of radioactive precursors into CEA and release by PI-PLC. LS-174T cell membranes labeled with $\left[{ }^{35}\right.$ S]cysteine (lanes $1-4$ ), $\left[{ }^{3} \mathrm{H}\right]$ palmitate (lanes 5 and 6 ), or $\left[{ }^{3} \mathrm{H}\right]$ ethanolamine (lanes 7 and 8 ) were treated for $6 \mathrm{~h}$ at $37^{\circ} \mathrm{C}$ with PI-PLC (B. thuringiensis, $3 \mathrm{U} / \mathrm{ml}$ ) or $10 \mathrm{mM}$ Tris, pH 7.4 (control lanes). After incubation, $\left[{ }^{3} \mathrm{H}\right]$ palmitate- and $\left[{ }^{3} \mathrm{H}\right]$ ethanolamine-labeled samples were immunoprecipitated with anti-CEA, applied to 7\% PAGE, and autoradiography was performed. The $\left[{ }^{35} S\right]$ cysteine-labeled samples were partitioned with Triton X-114 before immunoprecipitation. Lanes are labeled as described in Fig. 4. Control lanes: 1-2, 5, and 7. PIPLC lanes: $3-4,6$, and 8. 
Table III. Release of CEA from Human Colon Cancers by Incubation with PI-PLC

\begin{tabular}{clcc}
\hline & & \multicolumn{2}{c}{ CEA release: portion of total CEA } \\
\cline { 3 - 4 } Tumor number & Tumor location* $^{*}$ & DME Alone & DME + PI-PLC \\
\hline & & $\%$ & $\%$ \\
1 & Sigmoid & 3.9 & 83.9 \\
2 & Cecum & 4.5 & 87.3 \\
3 & Ascending & 5.2 & 66.2 \\
4 & Cecum & 15.0 & 61.7 \\
5 & Liver met & 5.4 & 41.9 \\
6 & Rectum & 7.9 & 67.3 \\
7 & Sigmoid & 3.3 & 39.7 \\
\hline
\end{tabular}

* Sigmoid, sigmoid colon; ascending, ascending colon; liver met, liver metastasis.

${ }^{\ddagger}$ Freshly defrosted specimens were minced, washed, and incubated in PI-PLC (B. thuringiensis, $3 \mathrm{U} / \mathrm{ml})$ for $3 \mathrm{~h}$ at $37^{\circ} \mathrm{C}$. Total CEA represents the sum of cellular and released CEA.

treatment released substantial amounts of the cellular CEA from seven human colon cancer specimens (Table III).

Triton $X-114$ partitioning of colon cancer sera. Serum specimens obtained from five patients with colon cancer were analyzed by Triton X-114 partitioning (Fig. 7). The samples were selected because of their unusually high CEA concentrations (see legend to Fig. 5), which is necessary for accurate CEA detection using these methods. In these experiments, the CEA in LS-174T cell membranes, which was used as a control, partitioned exclusively into the hydrophobic, detergent phase. In contrast, each serum sample contained substantial amounts of CEA which partitioned into the aqueous phase and resembled the CEA released by colon cancer cells in vitro. No bands were seen using control serum samples containing $<5 \mathrm{ng}$ $\mathrm{CEA} / \mathrm{ml}$ (not shown). In addition to the hydrophilic CEA, most samples contained hydrophobic CEA. The presence of both molecular forms of CEA suggests that there may be more than one mechanism for CEA release from colon cancers in vivo.

In addition to the 200-kD CEA, most of the samples also revealed detectable levels of lower molecular mass material which may indicate the presence of partially degraded CEA or of CEA-related antigens, such as the nonspecific cross-reacting

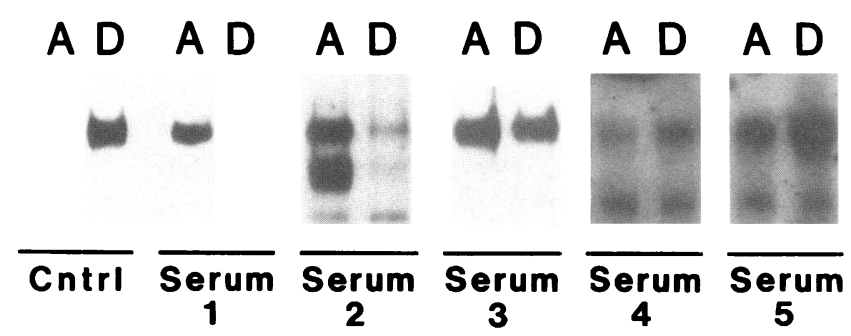

Figure 7. Triton X-114 partitioning of colon cancer sera. LS-174T cell membranes (Cntrl) and samples of serum from patients with colon cancer were partitioned with Triton X-114, immunoprecipitated with anti-CEA, and immunoblotted. Lanes are labeled as described for Fig. 4. Specific serum CEA content: $1,2,740 \mathrm{ng} / \mathrm{ml} ; 2$, $405 \mathrm{ng} / \mathrm{ml} ; 3,4,050 \mathrm{ng} / \mathrm{ml} ; 4,237 ; 5,424$. antigen-2, which are expressed by normal human leukocytes as well as by some colon cancers (1) and which are known to be immunoprecipitated by the antiserum used (24).

\section{Discussion}

Four mechanisms have been proposed for the release of membrane-associated glycoproteins in vivo, including cell lysis (25), shedding of plasma membrane vesicles $(25,26)$, cleavage by proteases (25), and release due to the action of phospholipases $(7,23)$. The present experiments were designed to determine the nature of the membrane-binding domain of CEA and to study the mechanism of CEA release in vitro and in vivo. The results suggest that CEA is attached to membranes by a glycosyl-phosphatidylinositol linkage and that an endogenous phospholipase may be responsible for the release of human colon cancer CEA.

We first established that CEA release by the human colon cancer cell line LS-174T is an active process not accompanied by significant LDH release (Table I) or light-microscopic evidence of impairment of plasma membrane integrity. Cellular CEA is predominantly membrane bound and hydrophobic, based upon its buoyant density and partitioning into the detergent phase of a Triton X-114-water mixture (16). The interaction with membranes appears to be nonionic since CEA is not dislodged from cell membranes with hypertonic or hypotonic buffers (Fig. $5 \mathrm{~B}$ ). In contrast, released CEA is a soluble, hydrophilic molecule, indicating that CEA release is associated with a change in CEA molecular form.

Significant amounts of membrane vesicles containing CEA were not detected in the medium by ultracentrifugation or by Sepharose CL-4B chromatography. Therefore, neither cell death nor membrane vesiculation is responsible for CEA release by LS-174T cells.

Several studies have demonstrated that exogenous proteases, including trypsin, elastase, papain, and bromelain, will release cell surface glycoproteins in vitro (27-30). In addition, there are endogenous proteases on gastrointestinal cells which could, in principle, play a role in glycoprotein release $(31,32)$. However, extensive incubation of LS-174T cell membranes with different proteases had no effect upon CEA hydrophobicity or solubility despite using more exhaustive incubation conditions than those reported previously (28-31).

Of the six phospholipase preparations incubated with cell membranes, only the three PI-PLCs converted CEA to the hydrophobic form or released significant amounts from cell membranes. It is unlikely that these results are due to the presence of contaminating proteases. Each PI-PLC preparation was free of protease activity when tested using azocasein as substrate (20). In addition, no proteolysis was detected when the $B$. cereus PLC preparation was incubated with BSA, human immunoglobulin $\mathrm{G}$, or human insulin for $6 \mathrm{~h}$ followed by SDS-PAGE and Coomassie Blue staining (results not shown).

The ability of PI-PLC to release CEA from LS-174T cell membranes, from living LS-174T cells in culture, and from specimens of human colon cancers indicates that CEA is anchored to cell membranes by covalently linked phosphatidylinositol. This mechanism of membrane attachment has been proposed recently for several other cell surface glycoproteins (23). These glycoproteins are attached to membranes by an 
amide bond between the $\mathrm{COOH}$-terminus amino acid of the glycoprotein and a short linking oligosaccharide which is covalently linked to the inositol head group of an intramembranal phosphatidylinositol (22). The fatty acids of phosphatidylinositol anchor the glycoprotein and make it hydrophobic. Consistent with the present results for CEA, glycoproteins in this class can all be released from membranes in vitro by incubation with preparations of purified bacterial PI-PLC $(23,27)$ and release by PI-PLC is associated with the conversion of the glycoprotein to a hydrophilic form. It is also characteristic of these glycoproteins that release is associated with no change in molecular weight detectable by conventional 7\% PAGE since only a diacylglycerol moiety is removed (23).

The composition of the linking oligosaccharide has been determined partially for two of these glycoproteins-mouse Thy-1 and variant surface glycoprotein (VSG) of Trypanosoma brucei-and found to contain stoichiometric amounts of ethanolamine, mannose, galactose, and glucosamine $(22,33$, 34). Our data showing that membrane-bound CEA incorporates both $\left[{ }^{3} \mathrm{H}\right]$ ethanolamine and $\left[{ }^{3} \mathrm{H}\right]$ palmitate, and that only the latter is released by PI-PLC, is further evidence that CEA contains the glycosyl-phosphatidylinositol structure (Fig. 6).

Another feature of this attachment mechanism that we have observed for CEA is that treatment with PI-PLC usually releases the majority, but not all, of the membrane-bound glycoprotein $(23,27)$. Two hypotheses have been proposed to explain this finding. First, some glycoproteins, such as the neural cell adhesion molecule (N-CAM), can be anchored by either glycosyl-phosphatidtylinositol or by a hydrophobic peptide sequence (35). Second, human erythrocyte membrane acetylcholinesterase has been reported to have a palmitic acid residue substituted at the $2-\mathrm{OH}$ of the inositol ring $(23,36)$. Modifications such as this may be responsible for the observed partial resistance to PI-PLC (23). In the case of CEA, the removal of $\left[{ }^{3} \mathrm{H}\right]$ palmitate by PI-PLC (Fig. 6) makes a palmitic acid substitution unlikely but does not rule out either of the aforementioned hypotheses.

These results for CEA are the first evidence that a tumorassociated glycoprotein may be released by a phospholipase under physiological conditions. In the cases of other glycosylphosphatidylinositol-linked glycoproteins for which the release mechanism has been studied, it is uncertain whether release by endogenous phospholipases occurs in intact cells and whether the enzyme responsible is a phospholipase $C$ or phospholipase D (37-39). The release of VSG caused by the $T$. brucei PI-PLC is only observed under conditions of osmotic or cold detergent lysis (40), and the phospholipase D-like activity described recently in the serum of several mammalian species, including humans, releases VSG from $T$. brucei only in the presence of detergent $(37,38)$. Similarly, the release of placental alkaline phosphatase from human placenta by an endogenous phospholipase $\mathrm{D}$ requires activation by butanol or detergent (35).

Serum from patients with colon cancer contains substantial quantities of hydrophilic CEA (Fig. 7), suggesting that an endogenous phospholipase releases CEA in vivo. However, hydrophobic CEA was also detected in most specimens. We interpret this as indicating that more than one release mechanism may be operative in vivo: hydrophilic CEA results from phospholipase action and hydrophobic CEA may be the result of cancer cell death which releases CEA into the circulation still attached to the hydrophobic phosphatidylinositol anchor.
Because LS-174T cells release CEA in the hydrophilic form when incubated in serum-free medium, it is not likely that the hydrophilic CEA observed in human serum was released from cells in a hydrophobic form and subsequently converted to the hydrophilic form by a serum phospholipase. Further experiments are in progress to address these questions.

\section{Acknowledgments}

The authors wish to thank Dr. Steven Itzkowitz for providing human colon cancer specimens.

This work was supported by American Cancer Society grant PDT-293 and by the U.S. Veterans Administration Research Service. Dr. Sack is an Associate Investigator and Dr. Kim is a Medical Investigator of the Veterans Administration. Dr. Low is supported by the American Heart Association and by National Institutes of Health grant GM-35873.

\section{References}

1. Rogers, G. T. 1983. Carcinoembryonic antigens and related glycoproteins: molecular aspects and specificity. Biochim. Biophys. Acta. 695:227-249.

2. Fletcher, R. H. 1986. Carcinoembryonic antigen. Ann. Intern. Med. 104:66-73.

3. Phil, E., J. McNaughtan, J. Ma, H. A. Ward, and R. C. Nairn. 1980. Immunohistological patterns of carcinoembryonic antigen in colorectal carcinoma: correlation with staging and blood levels. Pathology. 12:7-13.

4. Goslin, R., M. J. O'Brien, G. Steele, R. Mayer, R. Wilson, J. M. Corson, and N. Zamcheck. 1981. Correlation of plasma CEA and CEA tissue staining in poorly differentiated colorectal cancer. Am. J. Med. 71:246-253.

5. Thomas, P., and N. Zamcheck. 1983. Role of the liver in clearance and excretion of circulating carcinoembryonic antigen (CEA). Dig. Dis. Sci. 28:216-224.

6. Hamada, Y., M. Yamamura, K. Hioki, M. Yamamoto, H. Nagura, and K. Watanabe. 1985. Immunohistochemical study of carcinoembryonic antigen in patients with colorectal cancer. Cancer. 55:136141.

7. Low, M. G. 1981. Phosphatidylinositol-specific phospholipase C from staphylococcus aureus. Methods Enzymol. 71:741-746.

8. Podolsky, D. K., and K. J. Isselbacher. 1983. Composition of human colonic mucin: selective alteration in inflammatory bowel disease. J. Clin. Invest. 72:142-153.

9. Tom, B. H., L. P. Rutzky, M. M. Jakstys, R. Oyasu, C. I. Kaye, and B. D. Kahan. 1976. Human colonic adenocarcinoma cells I. Establishment and description of a new line. In Vitro (Rockville). 12:180-191.

10. Hwang, W. I., T. L. Sack, and Y. S. Kim. 1986. Effects of cyclic adenosine 3':5'-monophosphate upon glycoprotein and carcinoembryonic antigen synthesis and release by human colon cancer cells. Cancer Res. 46:3371-3374.

11. Bergmeyer, H.-U., E. Bernt, and B. Hess. 1963. Lactate dehydrogenase. In Methods of Enzymatic Analysis. H.-U. Bergmeyer, editor. Academic Press, Inc., New York. 736-741.

12. Bradford, M. M. 1976. A rapid and sensitive method for the quantitation of microgram quantities of protein utilizing the principle of protein-dye binding. Anal. Biochem. 72:248-254.

13. Knipe, D. M., D. Baltimore, and H. F. Lodish. 1977. Separate pathways of maturation of the major structural proteins of vesicular stomatitis virus. J. Virol. 21:1128-1139.

14. Braell, W. A., and H. F. Lodish. 1981. Biosynthesis of the erythrocyte anion transport protein. J. Biol. Chem. 256:11337-11344.

15. Burnette, W. N. 1981. "Western blotting": electrophoretic transfer of proteins from sodium dodecyl sulfate-polyacrylamide gels 
to unmodified nitrocellulose and radiographic detection with antibody and radioiodinated protein A. Anal. Biochem. 112:195-203.

16. Bordier, C. 1981. Phase separation of integral membrane proteins in Triton X-114 solution. J. Biol. Chem. 256:1604-1607.

17. Tsao, D., and Y. S. Kim. 1978. Glycoproteins from human colonic adenocarcinoma. Isolation and characterization of cell surface carcinoembryonic antigen. J. Biol. Chem. 253:2271-2278.

18. Baumann, H., E. Hou, and D. Doyle. 1980. Insertion of biologically active membrane proteins from rat liver into the plasma membrane of mouse fibroblasts. J. Biol. Chem. 255:10001-10012.

19. Gum, J. R., and H. W. Strobel. 1981. Isolation of the membrane-binding peptide of NADPH-cytochrome P-450 reductase. $J$. Biol. Chem. 256:7478-7486.

20. Beynon, R. J., J. D. Shannon, and J. S. Bond. 1981. Purification and characterization of a metallo-endoproteinase from mouse kidney. Biochem. J. 199:591-598.

21. Ikezawa, H., and R. Taguchi. 1981. Phosphatidylinositol-specific phospholipase $\mathrm{C}$ from Bacillus cereus and Bacillus thuringiensis. Methods Enzymol. 71:731-741.

22. Ferguson, M. A. J., M. G. Low, and G. A. M. Cross. 1985. Glycosyl-sn-1,2-dimyristylphosphatidylinositol is covalently linked to Trypanosoma brucei variant surface glycoprotein. J. Biol. Chem. 260:14547-14555.

23. Low, M. G., and A. R. Saltiel. 1988. Structural and functional roles of glycosyl-phosphatidylinositol in membranes. Science (Wash. DC). 239:268-275.

24. Tsutsume, Y., H. Nagura, and K. Watanabe. 1984. Immunohistochemical observations of carcinoembryonic antigen (CEA) and CEA-related substances in normal and neoplastic pancreas. Am. J. Clin. Pathol. 82:535-542.

25. Nowotny, A. 1983. Shedding eucaryotic cells. In Biomembranes, Volume V. Pathological Membranes. A. Nowotny, editor. Plenum Press, New York. 21-52.

26. Trams, E. G., C. J. Lauter, N. Salem Jr., and U. Heine. 1981. Exfoliation of membrane ecto-enzymes in the form of micro-vesicles. Biochim. Biophys. Acta. 645:63-70.

27. Seetharam, B., C. Tiruppathi, and D. H. Alpers. 1986. Hydrophobic interactions of brush border alkaline phosphatases: the role of phosphatidylinositol. Arch. Biochem. Biophys. 253:189-198.

28. Kapeller, M., R. Gal-Oz, N. B. Grover, and F. Doljanski. 1973. Natural shedding of carbohydrate-containing macromolecules from cell surfaces. Exp. Cell Res. 79:152-158.
29. Brower, M. S., R. I. Levin, and K. Garry. 1985. Human neutrophil elastase modulates platelet function by limited proteolysis of membrane glycoproteins. J. Clin. Invest. 75:657-666.

30. Jemmerson, R., J. L. Millan, F. G. Klier, and W. H. Fishman. 1985. Monoclonal antibodies block the bromelain-mediated release of human placental alkaline phosphatase from cultured cancer cells. FEBS (Fed. Eur. Biochem. Soc.) Lett. 179:316-320.

31. Chung, Y. S., I. S. Song, R. H. Erickson, M. H. Sleisenger, and Y. S. Kim. 1985. Effect of growth and sodium butyrate on brush border membrane-associated hydrolases in human colorectal cancer cell lines. Cancer Res. 45:2976-2982.

32. Ahnen, D. J., J. R. Singleton, T. C. Hoops, and T. M. Kloppel. 1986. Posttranslational processing of secretory component in the rat jejunum by a brush border metalloprotease. J. Clin. Invest. 77:18411848.

33. Tse, A. G. D., A. N. Barclay, A. Watts, and A. F. Williams. 1985. A glycophospholipid tail at the carboxyl terminus of the thy-1 glycoprotein of neurons and thymocytes. Science (Wash. DC). 230:1003-1008.

34. Cardoso de Almeida, M. L., and M. L. Turner. 1983. The membrane form of variant surface glycoproteins of Trypanosoma brucei. Nature (Lond.). 302:349-352.

35. Hemperly, J. J., G. M. Edelman, and B. A. Cunningham. 1986. cDNA clones of the neural cell adhesion molecule (N-CAM) lacking a membrane-spanning region consistent with evidence for membrane attachment via a phosphatidylinositol intermediate. Proc. Natl. Acad. Sci. USA. 83:9822-9826.

36. Roberts, W. L., B. H. Kim, and T. L. Rosenberry. 1987. Differences in the glycolipid membrane anchors of bovine and human erythrocyte acetylcholinesterases. Proc. Natl. Acad. Sci. USA. 84:7817-7821.

37. Low, M. G., and A. R. S. Prasad. 1988. Phospholipase D specific for the phosphatidylinositol anchor of cell surface proteins is abundant in plasma. Proc. Natl. Acad. Sci. USA. 85:980-984.

38. Davitz, M. A., D. Hereld, S. Shak, J. Krakow, P. C. Englund, and V. Nussenzweig. 1987. A glycan-phosphatidylinositol-specific phorpholipase D in human serum. Science (Wash. DC). 238:81-84.

39. Malik, A. S., and M. G. Low. 1986. Conversion of human placental alkaline phosphatase from a high $M_{\mathrm{r}}$ form to a low $M_{\mathrm{r}}$ form during butanol extraction. Biochem. J. 240:519-527.

40. Low, M. G. 1987. Biochemistry of the glycosyl-phosphatidylinositol membrane protein anchors. Biochem. J. 244:1-13. 